\title{
Conceptualizing knowledge creation: a critique of Nonaka's theory.
}

Stephen Gourlay

Kingston Business School

Kingston University

Kingston Hill

Kingston upon Thames

KT2 7LB

gourlaysn@kingston.ac.uk

02085478683 


\section{Conceptualizing knowledge creation: a critique of Nonaka's theory ${ }^{1}$}

ABSTRACT Nonaka's proposition that knowledge is created through the interaction of tacit and explicit knowledge involving four modes of knowledge conversion is flawed. Three of the modes appear plausible but none are supported by evidence that cannot be explained more simply. The conceptual framework omits inherently tacit knowledge, and uses a radically subjective definition of knowledge: knowledge is in effect created by managers. A new framework is proposed suggesting that different kinds of knowledge are created by different kinds of behaviour. Following Dewey, nonreflectional behaviour is distinguished from reflective behaviour, the former being associated with tacit knowledge, and the latter with explicit knowledge. Some of the implications for academic and managerial practice are considered.

KEYWORDS knowledge creation; knowledge management; knowledge types; tacit knowledge

\section{INTRODUCTION}

In The Knowledge-Creating Company (1995, pp. 6-7) Nonaka and Takeuchi claimed that the emphasis western companies placed on managing knowledge had not been accompanied by an understanding of how it is created. Nonaka ${ }^{2}$ proposed that organizational knowledge is created through the continuous social interaction of tacit and explicit knowledge involving four sequential modes of knowledge conversion: socialization, externalization, combination and internalization, before returning once more to socialization. This process is a 'spiral' one, a metaphor suggesting that each 'circuit' builds on the previous one; knowledge creation is also, implicitly, knowledge accumulation (Nonaka, 1991a; Nonaka, 1994, pp. 15, 18; Nonaka et al., 1994; Nonaka, 1995; Nonaka and Takeuchi, 1995, pp. 56, 61-2, 71-2, 89, 237-38; Nonaka and Toyama, 2003; Nonaka et al., 2001a, pp. 14-18). The process was depicted by a matrix, sometimes called the SECI model, described as the "engine" of the entire knowledge creation process (Nonaka and Takeuchi, 1995, p. 57; see Figure 1).

\section{INSERT FIGURE 1 ABOUT HERE}


Nonaka's theory has achieved paradigmatic status since the mid-1990s. ${ }^{3}$ It has been described as one of the best known and most influential models in knowledge strategy literature (Choo and Bontis, 2002, p. ix) and as "highly respected" (Easterby-Smith and Lyles, 2003, p. 11). While other parts of the theory (Nonaka, 1994, pp. 20-35; Nonaka and Takeuchi, 1995, pp. 70-90) have undergone considerable modification since the 1990s (Nonaka et al., 2001a, b) the "engine" remains a central element, recently being described as the way firms synthesize contradictions (Nonaka and Toyama, 2003).

The theory appears to have attracted little systematic criticism, at least not in management and organizational studies literature. ${ }^{4}$ The most far-reaching critique is in a neglected paper by Essers and Schreinemakers (1997). They praised Nonaka for recognizing that the capacity for corporate action depends on ideas and beliefs as much as on scientific knowledge but concluded that his subjectivism tended towards a dangerous relativism because he made justification a matter of managerial authority, and neglected to consider how scientific criteria relate to corporate knowledge. Second, he failed to recognize that the commitment of different groups to their ideas and the resulting need to resolve this conflict by managerial authority cannot bode good for creativity and innovation. Another comprehensive but neglected critique (Jorna, 1998) charged Nonaka with overlooking learning theory, earlier discussion of tacit and explicit knowledge, with misreading important organizational writers, and of not using better accounts of western philosophy. Bereiter (2002, pp. 175-179) argued Nonaka's model does not explain how new ideas are produced, nor how depth of understanding (necessary for expertise) develops. Further, their model of knowledge work is unconvincing, and they make collaborative work a mystery. These are not the only criticisms, but they are some of the most comprehensive and serious. ${ }^{5}$

Jorna's critique centred on the neglect of previous research, while Essers and Schreinemakers, and Bereiter, were largely concerned with consequences of the model. In the first part of this paper the focus will be on evaluating Nonaka's knowledge creation hypothesis, the "engine" of knowledge conversion/creation, and the associated concepts. It will be argued that the evidence adduced in support of the modes of knowledge conversion is either non-existent, anecdotal, or open to alternative explanations. More serious are the conceptual weaknesses of the framework, in particular the omission of inherently tacit knowledge, and the redefinition of 'knowledge' to mean managers' beliefs about, for example, the viability of new product ideas. Indeed, from this perspective, it appears Nonaka argues that knowledge is created 
when managers decide something is knowledge for the organization.

The second part of the paper turns to consider knowledge creation. Building on the consensus that there are, roughly speaking, two types of knowledge (not corresponding precisely to the categories tacit and explicit), it is argued that these correspond to Dewey's ([1916]) distinction between non-reflectional and reflective experiences. This leads to the inference that different forms of knowledge are created as a consequence of, and implicated in, different modes of experience/behaviour.

\section{KNOWLEDGE CONVERSION: THE EVIDENCE}

This section focuses on assessing the evidence cited in support of the four modes of knowledge creation. For this purpose Nonaka's central propositions about knowledge creation processes are taken for granted. They will be examined in the next section.

\section{Socialization}

Knowledge conversion, we are told, begins with the tacit acquisition of tacit knowledge by people who do not have it from people who do. Nonaka distinguished technical tacit knowledge (concrete know-how and skills) from cognitive tacit knowledge (mental models of the world). The socialization of the former was illustrated by a story about the development of a domestic bread-making machine, and of the latter with reports about brainstorming camps, and customer interaction (Nonaka, 1994, p. 16; Nonaka and Takeuchi, 1995, pp. 8, 60).

The first prototype bread-making machine failed to produce "tasty bread" and as a master chef could not tell the development team what they needed to know a team member apprenticed herself to him to learn the appropriate skills (Nonaka, 1991a, pp. 98-9; Nonaka and Takeuchi, 1995, pp. 63-4, 100-109). One day she "noticed the baker was not only stretching but also "twisting" the dough, which turned out to be the secret for making tasty bread" (Nonaka and Takeuchi, 1995, p. 64). Here as elsewhere (Nonaka and Takeuchi, 1995, p. 105) the taste of bread is the focus, but they also reported that during this phase "the team had to resolve the problem of getting the machine to knead the bread correctly" (Nonaka and Takeuchi, 1995, p. 105). Whether taste or kneading was at issue is important as it affects how we evaluate the data.

We are asked to take as evidence of socialization the engineers' ability to make a machine capable of baking tasty bread only after their apprenticeship to the chef where 
one team member noticed an aspect of the kneading action. Subjectivity aside, the taste of bread is influenced by the raw ingredients, the dough maturation process and by baking (Barfield, [1947], pp. 95-8), but not by kneading. The taste problem was probably solved incidentally during the lengthy development process when numerous other changes were made. Misattribution of reasons for success is to be expected (Nisbett and Wilson 1977), and even affects scientists who by virtue of their training and values might be expected to accurately report their achievements (see e.g. Collins, 1974, 2001a). If, on the other hand, the problem lay with kneading, although the description lacks sufficient detail to be certain what the "twist" actually refers to, noticing and replicating how the chef manipulated the dough may well have been important. The bread machine study may thus provide evidence for the socialization of technical tacit knowledge, but this is far from clear.

The stories of brainstorming camps, and customer interaction (Nonaka and Takeuchi, 1995, pp. 63-64; see also Nonaka, 1988a, p. 11; Nonaka and Kenney, 1991, p. 72) are too insubstantial to evaluate but a later study (Ichijo et al., 1998, pp. 173-203) appears to illustrate cognitive tacit knowledge socialization. A manager explained that interaction with customers was felt to be particularly important for product development: “ ' ... We come to understand what they [i.e. customers] want to do while talking with them about various things." " by “ " ... read[ing] into their thoughts and desires."” (Ichijo et al., 1998, pp. 184-5). As another manager said, “... 'we come to see what our customers expect towards the future while we listen, consider various problems and forecast upcoming changes with them'...." (Ichijo et al., 1998, p. 181).

It is difficult to accept these statements as evidence of anything other than the managers' beliefs about how they got ideas for new products. Had it been shown, by using techniques like cognitive mapping (Fletcher and Huff, 1990) for example, that customers tacitly held new product ideas; that they did not explicitly convey these to managers; but that managers' cognitive maps after talking with customers revealed evidence of new ideas similar to those of the customers, then perhaps there might be some justification in claiming that the socialisation of tacit cognitive knowledge can occur. No such evidence appears to have been produced.

\section{Externalization}

Socialization is followed by externalization, the conversion of tacit into explicit knowledge (Nonaka, 1994, p. 24; Nonaka and Takeuchi, 1995, p. 66), which was 
exemplified by anecdotes about new product development. The Honda City case is the most detailed and tells how after several false starts new ideas began flowing under the stimulus of the phrase "Automobile Evolution" eventually resulting in a new design. The other cases appear to involve similar processes and evidence (Imai et al., 1985; Nonaka, 1988a, pp. 9-12; 1990, p. 35; 1991a, pp. 100-101; Nonaka and Takeuchi, 1995 pp. 11-13, 69-70, 76-8, 86-7. See also Nonaka, 1988b; Nonaka and Kenney, 1991; Nonaka and Yamanouchi, 1989).

In using these cases to illustrate the externalization of tacit knowledge Nonaka and his colleagues make two important but implicit claims. First, that the designers' ideas had been held tacitly beforehand since it was their tacit knowledge that was externalized. No evidence, such as might have been demonstrated through cognitive mapping, was produced to support this. The second implicit claim is that externalization proceeds by use of metaphor and analogy, a hypothesis proposed earlier by Nonaka (Nonaka, 1991b; see also Nonaka and Takeuchi, 1995, pp. 66-67). Since this hypothesis is untested, and we use metaphor and analogy in all our linguistic practices (Lakoff and Johnson, 1980) either these cases do not illustrate externalization, or we are always externalizing whenever we speak, and so no special process needs to be invoked.

Nonaka did not present evidence for the externalization of technical tacit knowledge but the bread-machine case could be interpreted in this light: it seems likely that once the engineers had learned how to knead bread they were able to ground the development and re-design of the prototype in this shared experience. Whether it makes sense to conceptualize this in terms of the externalization of a tacit skill is a question explored below.

\section{Combination}

The interaction of explicit knowledge with explicit knowledge or "combination" was described as the process of "systematizing concepts into a knowledge system" (Nonaka and Takeuchi, 1995, p. 67). Nonaka's examples include writing a report (Nonaka, 1991a, p. 99); meetings, conversations, and exchange of documents (Nonaka, 1994, p. 19; Nonaka and Takeuchi, 1995, p. 67); an MBA education ("one of the best examples" [Nonaka and Takeuchi, 1995, p. 67]); “[m] odern computer systems” (Nonaka, 1994, p. 19); and the 'embodiment' of knowledge into products (Nonaka, 1991a, p. 99; Nonaka et al., 1996, pp. 207-8). 
Adler (1995, p. 111) suggested Nonaka's claim that an MBA simply involves exchange of explicit knowledge might be a "playful" remark, the case study method having been designed to help transmit tacit knowledge. Documents have been treated as channels along which messages pass to the reader but this has long been criticized as an inadequate model (e.g. Cherry, 1966). Computer functioning and knowledge 'embodiment' processes might well be viable candidates for a distinct 'combination' process, but as they have not been described, we cannot be certain. Ahituv (1987), for example, identified the transformation of data/information from one medium to another as a special aspect of information systems, and this might be what Nonaka meant by "combination". The lack of detail in any of these examples precludes further discussion.

\section{Internalization}

Internalization, the conversion of explicit into tacit knowledge, is "closely related" to "the traditional notion of learning", and to "learning by doing" (Nonaka et al., 1994, pp. 340-41; Nonaka, 1994, p. 19; Nonaka and Takeuchi, 1995, p. 69). Saying that internalization is 'closely related' to learning implies it is distinct from learning while claiming that it is 'triggered' by learning-by-doing (Nonaka et al., 1996, p. 208) suggests learning causes internalization.

Nonaka and Takeuchi claimed that reading illustrates the process of cognitive tacit knowledge internalization as readers re-experience writers' experiences, thus transferring tacit knowledge (Nonaka and Takeuchi, 1995, pp. 69-70). Given that they also suggest that tacit knowledge arises from one's own experiences (Nonaka and Takeuchi, 1995, pp. 60-61) it is unclear how reading might generate tacit knowledge of what is being read about. It should only generate tacit knowledge of reading and related processes. The copious research into reading (e.g. Smith, 1994) appears not to provide any support for their claim. They also suggested that internalization is exemplified by the case of workers who discovered what working reduced annual hours felt like by working for a month at the new rate (Nonaka and Takeuchi, 1995, pp. 70, 117-20). However, since the ability to do without the ability to tell is typically held to be the primary form of evidence for tacit knowledge, the evidential status of feelings is unclear. Internalization, as the acquisition of tacit knowledge from explicit knowledge, appears difficult to illustrate, and their examples are not convincing. 


\section{The evidence reconsidered}

We therefore only appear to have reasonably good evidence for the socialization and externalization of technical tacit knowledge, provided by the bread-making study. However, this evidence can be interpreted more simply than in terms of interacting knowledge forms. First there is no need to suggest that when someone learns under the guidance of an expert that some indescribable kind of knowledge is 'transferred' by an unknown process. People regularly learn new skills without direct personal contact with an expert which testifies to the centrality of learning-by-doing for acquiring skills. An expert's role may often be to constrain novices' freedom of action such that they develop the appropriate skills (Tsoukas, 2003, p. 424; Williams et al., 1999, p. 337), or to provide exemplary behaviour that the novice unconsciously imitates, a process explicable in terms of action perception processes (see Schaal et al., 2003; Wohlschläger et al., 2003).

As for externalization, Nonaka's emphasis on figures of speech suggests it is a linguistic process through which, mysteriously, tacit knowledge becomes explicit. A report of an apparently identical process amongst scientists (Collins, 2001a) suggests active exploration and experimentation rather than metaphor laden talk were the critical factors. Much experimentation apparently took place during prototyping of the bread machine (Nonaka and Takeuchi, 1995, pp. 104-107), but the role of these activities in the development of the machine was not reported.

The engineers' success might simply reflect a process of task design typical of modern organizations. Collins and Kusch's (1998) distinction between mimeomorphic and polimorphic tasks is helpful here. Mimeomorphic tasks are by definition machine-like. They admit of only one way of execution and their description will match the way the task was performed by people. Polimorphic tasks, in contrast, nearly always must be done in various ways, and any description is unlikely to match the kinds of input made by humans (Collins and Kusch, 1998). Practices such as bread-making are a mix of polimorphic and mimeomorphic tasks - kneading large quantities of dough by machine, for example, was commonplace in 1940s Britain, but the overall process still retained many craft elements (Barfield, [1947]).

In competitive economies, the set of tasks of any practice are often reorganized by transforming polimorphic tasks into more mimeomorphic ones, otherwise known as deskilling (Davids and Myers, 1990; Thompson, 1983). The bread-machine designers 
aimed to make a commercially viable machine that customers would feel made bread like that prepared by a chef. Their interest in the chef's polimorphic bread-making tasks, skills and associated tacit knowledge was marginally instrumental to solving an engineering problem that entailed designing a new bread production process. Within limits due to bread chemistry, for example, (and to the extent they did not modify that) the knowledge required to produce bread in the machine was quite different from that of the craft baker. Bereiter (2002, p. 177) pointed out that observation and attempted mimicry of birds did not enable us to fly; that required transformation of the problem. By analogy, the bread-machine designers did not 'externalize' the chef's bread-making knowledge into their machine; they transformed the problem into one that could be handled by a particular kind of machine. It is therefore not necessary to postulate tacitto-tacit and tacit-to-explicit knowledge transformations when we can more simply refer to learning by doing on the one hand, and to designing new tasks on the other.

Nonaka and his colleagues' attempt to provide a straightforward useable theory of knowledge creation was an ambitious one, and we should not be too surprised at difficulties like these. They are perhaps partly due to the derivation of the model from studies of information creation and innovation (Imai et al., 1985; Nonaka, 1988a; 1988b; 1990; 1991a; Nonaka and Kenney, 1991; Nonaka and Yamanouchi, 1989) rather than from empirical studies of organizational knowledge processes. Reinterpretation of old data is of course a valid method, but it might well also constrain new theory development. Nonaka called for more research to validate the modes, and the 'spiral' sequence (Nonaka et al., 1994, p. 350), work that on the whole still remains to be done. Research along some of the lines indicated above may well validate the ideas of socialization and externalization. However, there are more fundamental difficulties with the matrix concerning the conceptual framework.

\section{NONAKA'S CONCEPTUAL FRAMEWORK: CRACKS IN THE "ENGINE"?}

The existence of conceptual difficulties has already been hinted at in the foregoing discussion, particularly of combination and internalization. Both these processes are described as comprising a number of otherwise distinct activities, two of which (reading, and writing) are common to both. What unites these otherwise disparate activities to qualify them as either (or both) combination or internalization is not made clear in principle, or through the examples. This unexplained empirical heterogeneity, together with the introduction of a new aspect, feelings, suggests a lack of conceptual 
clarity.

Furthermore, if tacit knowledge is the source of new knowledge (itself an unsubstantiated claim) it is not clear why knowledge conversion has to begin with socialization. New tacit knowledge is also generated by internalization, so we are told, and if reading and writing are both instrumental in tacit knowledge formation, then knowledge creation might also begin with the creative synthesis of explicit knowledge ("combination"). Externalization too could form a starting point since all that is required is that some 'source' activity, and thus associated tacit knowledge, already exists. Finally, it is evident that Nonaka only proposed two modes of knowledge conversion, tacit to explicit, and explicit to tacit. Socialization and combination, however, are modes of knowledge transfer, the former concerning how one person or group acquires the tacit knowledge of others, and the latter the transfer of already existing explicit knowledge between containers (people, documents, computers).

That these difficulties hint at the existence of deeper conceptual problems becomes clear when we consider key aspects of Nonaka's conceptual framework directly. He claimed that knowledge is created through the interaction of tacit and explicit knowledge. Three concepts, tacit knowledge, explicit knowledge, and knowledge, (and their interrelationships) are thus central to his theory, which will now be examined in more detail.

\section{Tacit and explicit knowledge}

Nonaka attributed the concepts of tacit and explicit knowledge to Polanyi. Tacit knowledge is subjective, bodily, of the here and now, and practice-based, while explicit knowledge is objective, of the mind, and the there and then, and concerned with theory (Nonaka and Takeuchi, 1995, pp. 59, 61; see also Nonaka, 1994, p. 16). Tacit knowledge is difficult to communicate or share, but, they claimed, is a "rich untapped source of new knowledge" (Nonaka, 1994, p. 16; Nonaka and Takeuchi, 1995, pp. 8, 59-60, 72, 85; Nonaka et al., 2001a, p. 15). Nonaka distinguished technical from cognitive tacit knowledge to give Polanyi's ideas a more "practical" aspect (Nonaka, 1994, p. 16; Nonaka and Takeuchi, 1995, p. 60), a puzzling move given their critique of dualist thought (Nonaka and Takeuchi, 1995, pp. 25-32).

Citing the authority of Polanyi for 'tacit knowledge' causes difficulties since Polanyi used "knowledge" to mean a process, "knowing", not an object (Gourlay, 2004). Even 
so, his phrasing is sometimes ambiguous as when he wrote that "explicit knowledge must rely on being tacitly understood" (Polanyi, 1969, p. 144), a quotation that underlines the argument that for Polanyi there is always an irreducibly tacit aspect to any explicit knowledge/knowing (Adler, 1995; Gourlay, 2004; Tsoukas, 2003).

Nonaka and his colleagues are not alone in holding that tacit knowledge can be converted to explicit knowledge, or, that whatever remains is trivial (e.g. Boiral, 2002, p. 296; Spender, 1996, p. 58; Torff, 1999, p. 195; Wagner and Sternberg, 1986). Others, however, claim with equal conviction that at least some tacit knowledge cannot be made explicit (e.g. Ambrosini and Bowman, 2001, pp. 812-3; Collins, 2001a, p. 72; Herbig and Büssing, 2003, p. 167; Patel et al., 1999, p. 76; Tsoukas, 2003, p. 425). Collins (2001b), while deliberately conceding much of the debate to those who believe tacit knowledge can be explicated, argued that the "forms of life" by and through which we conduct our social practices cannot be made explicit, and thus remain a underlying tacitly known component (see also Janik, 1988; Tsoukas, 2003; Tsoukas and Vladimirou, 2001). A model of knowledge creation processes that begins with tacit knowledge must therefore account in some way for both inherently and contingently tacit knowledge, an issue that needs addressing if Nonaka's hypothesis about knowledge creation is to be defended.

\section{Explicit knowledge, and knowledge}

Nonaka and his colleagues' distinction between explicit knowledge, and knowledge, raises further conceptual difficulties. They say that explicit knowledge is another name for declarative knowledge (Nonaka, 1994, p. 18; Nonaka and Takeuchi, 1995, p. 61) but declarative, explicit and propositional are simply names used by different disciplines for the same conceptual object (Sahdra and Thagard, 2003, pp. 478-9). Moreover, "propositional knowledge", as used by epistemologists, means knowledge as "true, warranted belief" (Klein, 1998). ${ }^{6}$ We might therefore conclude Nonaka proposed that new (explicit) knowledge is created by the interaction of tacit knowledge and previously created (explicit) knowledge but Nonaka and his colleagues would not agree.

Their claim to have adopted the definition of knowledge as 'justified true belief' (Nonaka, 1994, p. 15; Nonaka and Takeuchi, 1995, p. 58) is misleading. Nonaka did say he had modified this definition considerably but he did not draw out the full implications of his modifications. He claimed that "for present purposes it is important to consider knowledge as a personal "belief," and to emphasize the importance of the 
"justification" of knowledge" (Nonaka, 1994, p. 15), a "critical" distinction because "traditional epistemology emphasizes the absolute, static, and nonhuman nature of knowledge" (Nonaka and Takeuchi, 1995, p. 58; Nonaka et al., 2001a, pp. 14-15). ${ }^{7}$

Regardless of the merits of this view it is not clear why this should be a problem except that if we assume knowledge is absolute and static the question of managing its creation can hardly be posed.

The consequences of Nonaka and his colleagues" cavalier dismissal of "traditional epistemology" become clear in the light of their discussion of justification, "the process of determining if the newly created concepts are truly worthwhile for the organization" (Nonaka and Takeuchi, 1995, p. 86; Nonaka, 1994, p. 26). This clearly, and solely, involves the evaluation by managers of new ideas against pre-defined criteria (Nonaka, 1994, p. 26; Nonaka and Takeuchi, 1995, pp. 86, 103, 108-9). Thus the first prototype bread-making machine failed to be "justified against the original product concept" because it did not make tasty bread. Even when this problem had been rectified the idea remained unjustified because it failed to meet cost criteria (Nonaka and Takeuchi, 1995, pp. 103-8). Moreover, since these criteria were "standards for judging truthfulness" (Nonaka, 1994, p. 26) Nonaka appears to say that if beliefs are justified in this sense, then they are also true. In so far as justification can be based on false premises (Klein, 1998, p. 268) a 'justified belief' may well be wrong. The practical implications of this move, however, are straightforward: 'knowledge' as 'justified belief' in Nonaka's framework simply means ideas and plans that have been sanctioned by managers. Knowledge and explicit knowledge are therefore quite different concepts for Nonaka. In this light it is clear that for Nonaka and his colleagues 'knowledge' means that fraction of warranted beliefs about processes and their associated facts that passes through the filter of managerial evaluation of what is and is not practicable for the organization. Such processes have been widely discussed in decision-making research (Bazerman, 1998) and it appears the matrix concerns decision making rather than knowledge creation. Nonaka's emphasis on the importance of personal commitment to knowledge processes (Nonaka, 1994, p. 17-18; Nonaka and Takeuchi, 1995, pp. 58-9) also makes sense in this context. No amount of personal commitment to a belief that the taste of bread is influenced by a "twist" can change the chemistry of baking, nor would it suffice when it comes to improving the design. On the other hand, personal commitment to a belief that a particular design will be commercially viable, and does meet previously specified criteria, is probably vital to success in battles over 
organizational priorities.

There can be no objection to distinguishing managers' reasoned beliefs about the viability of new product or process ideas from evidence about, for example, how breadmaking might be mechanized on a domestic scale. Calling both 'knowledge', and in particular discussing the former in the language of epistemology risks confounding the distinction, however, and thus confusing discussion about the creation and management of knowledge in organizations. Beliefs are of course important, and a theory of knowledge management might even encompass them, but a realistic model of knowledge creation must also account for the production of scientific type knowledge which is after all the foundation of our ability to control material and other processes. Nonaka and his colleagues' conceptual framework omits inherently tacit knowledge, and adopts a radically subjective definition of knowledge (Essers and Schreinemakers, 1997) focusing on the content of managers' decisions, and entirely omitting more scientific forms. These shortcomings are so fundamental that there is little point in considering their claim that knowledge is created through the social interaction of tacit and explicit knowledge. Indeed, their model clearly indicates that knowledge as they define it is primarily created by managerial decision. In so far as the matrix continues to figure in Nonaka and his colleagues' later model (e.g. Nonaka and Toyama, 2003) that too may be in need of revision, an issue beyond the scope of this paper. Instead we will focus on the important question of how we might conceptualize knowledge creation better, and whether or not it might be managed.

\section{KNOWLEDGE CREATION - TOWARDS A NEW FRAMEWORK}

Nonaka's suggestion to take knowledge creation seriously (e.g. Nonaka and Takeuchi, 1995) is a good one since if we understand how something is made we are in a better position to manage it than by dealing only with the symptoms of some underlying process. The remainder of this paper will attempt to address some of the issues this task involves, beginning with a brief review of what we might mean by 'knowledge'. It will be argued that the widespread distinction between two kinds of knowledge (roughly, tacit and explicit) reflects a distinction between two broad kinds of behaviour, one of which appears difficult but perhaps not impossible to manage, the other being perhaps better understood. 


\section{Knowledge: a "tricky" concept}

Alvesson and Kärreman (2001, pp. 997-1012) argued that use of "knowledge" in management literature suffers from five problems: ontological incoherence; vagueness; breadth, and hence conceptual emptiness; tensions between regarding it as objective, and evidence of its subjectivity; and functionalism. They concluded that knowledge is a loose, ambiguous, and rich concept that precludes reduction to simple sets of distinctions (see also Blackler, 2002, p. 54; Wilson, 2002), implicitly endorsing the conclusion reached half a century earlier that knowledge is one of those "“"vague words" one is at times compelled to use", "a "loose name" " that has been used to refer to a great many often different things (Dewey and Bentley, 1949, p. 48, 78).

The situation has not improved since the 1940s. While Bentley noted that at least knowledge was connected with "living organisms" (Ratner and Altman, 1964, p. 459) more recently it is said to be embedded/embodied in "technology" (Argote and Darr, 2000, p. 53), in documents, repositories, organizational routines, practices and norms, (Davenport and Prusak, 1998, quoted in Alvesson and Kärreman, 2001, 998-9), and in the "physical structure of the workplace" (Argote and Ingram, 2000, p. 152). Knowledge is indeed a "tricky" concept (Tsoukas and Vladimirou, 2001, p. 975)! We can, nevertheless, examine some ways in which the concept has been used to see whether these help us to conceptualize 'knowledge creation'.

Discussion of knowledge traditionally begins with philosophy but as knowledge management implies an alternative paradigmatic conception (Essers and Schreinemakers, 1997) it is probably better to begin elsewhere. Indeed, as Nonaka and Takeuchi apparently implied, the 'traditional' western view effectively prohibited questions about knowledge creation since knowledge was assumed to exist either in the environment, or in the organism (see e.g. Richardson, 1998). We will begin by reviewing discussion linking knowledge with information, since this has traditionally informed knowledge management, before proceeding to consider the implications of several knowledge typologies.

\section{Knowledge is transformed information?}

This theme is evident in various formulations about knowledge. Nonaka and his colleagues described knowledge as "a meaningful set of information" (Nonaka et al., 1996, p. 205; Nonaka and Takeuchi, 1995, pp. 58-9); Myers (1996, p. 2) called 
organizational knowledge "processed information", and Davenport et al., (1998, p. 43) described knowledge as "information combined with experience, context, interpretation and reflection.... a high-value form of information...". Different versions of this "value chain" model (Shin et al. 2001, p. 336) exist but all place knowledge above information (Bouthillier and Shearer, 2002; Liang 1994; Tuomi, 1999).

This suggests that knowledge is created through the transformation of information but no account is given of how information is 'constituted', 'processed', or 'combined' to yield knowledge or how it acquires 'high value'. Such processes imply the activity of a cognitive system (Garavelli et al., 2002, p. 271), but this is usually treated as some kind of inert machinery, a view perhaps in keeping with the widespread assumption that information is value-free (Day, 2000). Another difficulty is that regardless of whether information is value-laden or value-free, the word is used in a variety of ways, depending on the level of analysis (Stamper, 1996). Finally, Tuomi (1999) has convincingly argued that knowledge is needed to specify data: the hierarchy can be inverted and still make sense! Treatments of knowledge in terms of information are thus fraught with conceptual difficulties. The fact that 'information' and 'knowledge' are often used interchangeably (Bouthillier and Shearer, 2002; Shin et al. 2001, p. 336) and that there is little to distinguish knowledge management from information management (Wilson, 2002), provides further evidence of confusion, and suggests this approach currently offers little support to hypotheses about knowledge creation.

\section{Knowledge and knowledge types}

The idea that there are roughly two distinct kinds of knowledge is widely accepted. In knowledge management, the labels tacit and explicit are chiefly used, but other disciplines use different names (Table I). Here, Sahdra and Thagard's (2003, p. 479) labels have been used.

\section{INSERT TABLE I ABOUT HERE}

\footnotetext{
"Knowledge-how" covers knowledge that is situated or context dependent in so far as it does not appear meaningful to consider it as 'knowledge' apart from someone who knows and the situation in which they act. Other terms include process (Shin et al. 2001, p. 339), or processual knowledge (Kakihara and Sørensen, 2002, pp. 51-4). Included
} 
here are Gherardi and Nicolini’s (2000, pp. 330-33) “social-material constructionist approach"; connectionist and autopoietic perspectives (Smith and Samuelson, 2003; von Krogh et al. 1996; Venzin et al. 1998); and, since practices are social processes, the 'forms of life' approach (Collins, 2001b; Tsoukas, 2003; Tsoukas and Vladimirou, 2001). Cook and Brown's action oriented “epistemology of practice” (1999, p. 382), Blackler's emphasis on "knowing" linked with situated practices as distinct from "knowledge" (2002, p. 51, 54-56), and situated cognition (Clancey, 1997a) can also be placed here.

Knowledge-how perspectives are diverse, covering knowledge as interpretation, knowledge as process, and knowledge as relationship (Kakihara and Sørensen, 2002, pp. 51-54) and while this heterogeneity would elsewhere warrant emphasising distinctions, from the perspective of knowledge creation their context dependency unites them. These perspectives are also largely anti-representationistic viewing knowledge as not representable (or, not meaningfully representable) in symbolic form. Knowledge-how is not simply another name for tacit knowledge since it also covers in particular that explicit knowledge where context is critical to give it meaning, and where there is contextual variability in meanings attributed to the 'same' explicit knowledge.

The knowledge-that category covers knowledge in symbolic forms existing independently of individual knowers; it could be labelled 'decontextualized knowledge' and is all explicit in form. Kakihara and Sørensen (2002) called it the knowledge as object approach, and it has clear affinities with the "traditional" approach to knowledge (Blackler, 2002, pp. 48-54). An important feature, neatly captured in Cook and Brown's phrase the "epistemology of possession" (1999, p. 382), is that knowledge-that is held to be 'in' something, an approach consistent with the "representationistic" (Kakihara and Sørensen, 2002, p. 50) assumption that organisms have internal states carrying representations of salient parts of their environment (Bechtel, 1998; see also Clancey, 1997b, pp. 250-53). This assumption is widespread in knowledge management discourse where knowledge is said to be "embedded" in "repositories" (individuals, roles and structures, organizational practices, culture, and the physical structure of the workplace) or "reservoirs" (organization members, tools, and tasks, and combinations of these three elements) (Argote and Ingram 2000, pp. 152-153) or "materialized" into "knowledge object[s]", such as documents (Garavelli, et al. 2002, p. 270). ${ }^{9}$ 


\section{The everyday life-world and reflective experience}

So far we have considered knowledge, and a typology of knowledge types. To link this to knowledge creation, implicitly some kind of act, we have to shift the focus to what metaphorically lies behind or under these types. To do so we draw on an important distinction made by Dewey and later by Schutz.

Dewey proposed to distinguish between non-reflectional experiences, characteristic of our everyday living, and reflective experiences, typical of the professional behaviour of philosophers, or scientists (Dewey, [1916]). Dewey's non-reflectional experience has clear parallels with Schutz' notion of the everyday life-world wherein we act unreflectively (Schutz and Luckmann, 1974, p. 3). Thus knowledge-how, or knowing (to stress its processual aspect), is characteristic of the everyday life-world. Knowledgethat, on the other hand, "knowledge of and about things, knowledge that things are thus and so" is created by processes of "reflection and conscious appreciation" (Dewey, 1930, p. 178; see also [1916], pp. 4, 12-13, 17-21), a specific kind of experiencing and activity. Words like "reflection" and "theorizing" might be held to imply primarily linguistic processes akin to Nonaka's externalization but the intention here, drawing on Dewey ([1916], pp. 13-14), is that reflection covers the whole action-reflection-action cycle and not just its cerebral aspect. Thus while the immediate product of reflective activity may be communicable mappings (Holzner, 1972, p. 9) of those events that were the focus of reflection, such products are also typically an intermediate step in a process of seeking greater control over what has been reflected on.

The tacit knowledge fraction of know-how appears to be created in at least three ways. First it may be innate or due to instinct. Dewey noted that knowing how was an “outgrowth of unlearned activities which are part of man's endowment at birth" (Dewey, 1930, p. 89) and Torff (1999, p. 195) regarded innate predispositions as a particularly recalcitrant form of tacit knowledge. The idea of innate knowledge need not imply nativism or biological determinism since what appears as innate depends on particular organism-environment developmental conditions for its formation (Gottlieb, 2001).Tacit knowledge can also be acquired without awareness through implicit learning (e.g. Berry and Dienes, 1993). Finally, important aspects of expertise are exercised tacitly but were learned explicitly, and if experts' normal decision-making is disrupted they can 'recall' the relevant explicit knowledge (Ambrosini and Bowman, 2001; Patel et al., 1999). 
It is often held, largely following Polanyi, that tacit knowledge is 'personal' and therefore implicitly private. While we are each clearly in some respects unique, implying individually specific knowledge underpins our behaviour, in so far as we engage in practices, thus "acting in ways similar to others, with a view to achieving states of affairs which others also attempt to achieve, and using the same type of resource... to achieve that type of end." (Harris, 1980, p. 29, quoted in Reed, 1985, p. 119) then 'individual' tacit knowledge is simultaneously 'collective' at least to the extent of being shared "forms of life" (Collins, 2001b; Tsoukas, 2003).

Neuropsychological and anthropological models (Frith and Wolpert, 2003; Strauss and Quinn, 1997) help us understand how such 'sharing' is possible without conscious awareness or intent on the actors' part, and without invoking mysterious tacit knowing processes.

The explicit fraction of know-how is simply that of our everyday life-world language; our readily articulable commonsense beliefs that are at hand in any situation. These can often be elaborated - we can answer questions as to why we do something, but typically in the everyday life-world there is a limit beyond which we cannot go without slipping over into reflective activity. This appears to be what reference to our 'forms of life' (Collins, 2001b) means. As we move from the everyday life-world into that of reflective activity these cognitive limits, while remaining at some level, can be selectively pushed back. An astronomer, like the rest of us, knows that the sun rises every day, but in her professional life, knows this is an illusion yet accepts (and may even be unaware) that her calculations relating to astronomical phenomena rests on yet other unexamined assumptions.

Moving further, so to speak, into the reflective world(s) we find that a defining characteristic of, for example, scientific work is that the methods whereby knowledge is created are themselves explicit and open to question. While scientists cannot escape the psychological and sociological constraints of human decision making on the knowledge they produce (Bechtel and Richardson, 1998; Collins, 1974, 2001a, b) their methods can be described, reflected upon and improved, and, within the kinds of local limits described by research into scientific practices (Collins, 1974, 2001a) replicated by others. Such knowledge, whatever its limits, is thus often more reliable, as well as more likely to be systematically corrected, than that of the everyday life-world.

From this perspective it is clear that knowledge is not created by some relation (or 
"interaction") between two kinds of knowledge but through human activities or practices in general, on the one hand, and through a specific sub-set of practices ("theorizing is one practice amongst others" [Ryle, 1963, p. 27]) on the other. There is thus no opposition between the two, nor any need to assimilate one to the other; explicit knowledge is not 'externalized' tacit knowledge, but representations of abstractions from ongoing practices that appear salient to their understanding and the exercise of control over them, as well as useful for communicating with others.

\section{Managing knowledge creation}

It would appear that much know-how, especially aspects of tacit knowledge, may be beyond overt control, and thus management in an active sense. Instinct, as well as experiences that shaped someone's tacit knowledge before they enter into a specific employment relationship, are beyond the capacity of managers to influence directly. Of course, some experiences such as formal schooling, for example, partly function to inculcate work relevant tacit knowledge, and managers' actions can influence its reproduction in the workplace. In so far as tacit knowledge is created and maintained by ongoing experiences, managing cannot avoid influencing it as a consequence of implicit (Berry and Dienes, 1993) or incidental and informal (Garrick, 1998) learning processes. Decisions taken for one good (managerial) reason may have negative consequences for tacit knowledge. As Lado and Wilson (1994, p. 175) noted, Taylorised work practices can "inhibit the development of transformational competencies by promoting and reinforcing organisational 'defensive routines"”. Perhaps exercising "care” (von Krogh, 1998) may help to avoid such consequences, but as Popper and Lipshitz's (1998) review of psychological and sociological processes affecting learning at work shows, these are undoubtedly very complex. The issue of consciously influencing others' unconscious behaviours also raises important ethical questions. In so far as expertise develops through repeated exposure to similar problems, given prior explicit training, this type of tacit knowledge may be the easiest to manage. Accepting that tacit knowledge is created all the time, being shaped by people's experiences, should at least encourage the recognition that decisions taken for ostensibly good explicit reasons may have unintended and undesirable consequences that we should seek to inquire into before committing ourselves to decisions.

Managing explicit knowledge - both that which is part of knowledge-how and more particularly that which comprises knowledge-that - requires us to consider on the one 
hand to what extent common-sense processes of thinking and acting can be managed, and on the other, whether more systematic (scientific-type) methods can be used in organizations, and if so, how they can be managed effectively. The idea of questioning and thus to a degree managing common-sense processes is not a new one, having been addressed in terms of developing awareness of theory-in-use, and of seeking to modify it. It is, however, extremely difficult, and there is debate as to how far it is possible, or desirable, and whether or not it is compatible with other managerial objectives (Argyris and Schön, 1974; Friedman et al., 2001; Gray, 1996). This issue has obvious affinities with considering the potential unintended consequences of decisions referred to above. In so far as organizations conduct more formal scientific-type research, this kind of knowledge creation process has been managed for some time. Whether it is managed as effectively as it could be is another issue, and doubtless this area could benefit from drawing on, for example, studies of scientific and technical practices (Barley and Orr, 1997; Collins 1974, 2001a).

As regards consciously influencing (and thus managing) both commonsense and scientific knowledge creation processes, it is interesting to note that the presence of informed outsiders appears useful if not critical. Indeed, if one of the defining features of the forms of life constraint on explicit knowledge is that the participants in a practice typically are unaware of the presuppositions on which those practices depend, then the presence of outsiders is likely to be critical to making such assumptions explicit. The breakthrough in the bread-machine design was attributed to a software engineer who was not part of the engineering team as such (Nonaka and Takeuchi, 1995, p. 104). In Collins' study of sapphire quality measurement (2001a), it took the collaborative efforts of Russian and British scientists several days to identify the precise importance of specific aspects of the Russians' practices. The software engineer, and the British scientists, were both informed participants (they understood important aspects of the processes) but were outsiders, not being full members of the practices central to the problem at hand in each case. The role of psychologists in drawing up a tool to help managers become aware of the tacit assumptions on which they base important decisions (Wagner and Sternberg, 1986) as of outsiders for raising awareness of theories-in-use (Argyris and Schön, 1974) also testifies to the critical role of informed outsiders. 


\section{CONCLUSIONS}

Nonaka's proposition that knowledge is created through the interaction of tacit and explicit knowledge via four knowledge conversion processes has been found wanting on empirical and conceptual grounds. The bread-machine study provides the only evidence that warrants serious attention, and could be interpreted as showing evidence for both socialization, and externalization. However, the evidence is also open to alternative explanations that do not require us to explain the events in terms of interaction between forms of knowledge. Combination, and internalization, in particular, appear to be ambiguous notions, while knowledge conversion has been conflated with knowledge transfer in the matrix.

The underlying theory rests on a unidimensional view of tacit knowledge, ignoring views that tacit knowledge may be at least partially if not wholly inherently tacit. The distinction between explicit knowledge and knowledge seems unclear, until on examination it is evident that Nonaka and his colleagues have re-defined knowledge to mean 'justified belief'. This is more than simply a contraction of the traditional (western) epistemological definition of knowledge, since it refers specifically to managers' beliefs, justified with respect to prior strategic decisions, and to forecasts. 'Knowledge' concerning for example certainties about how to control things to effect desired goals (such as making tasty bread) remains unaccounted for in this model. It is therefore less a model or theory of knowledge creation through knowledge conversion, than one concerning managerial decision-making.

In so far as 'knowledge' is an important factor in contemporary societies and organizations, and on the assumption that it is created in some sense, then clearly it is worth developing an understanding of such processes. It is notoriously difficult to define 'knowledge' satisfactorily, but, building on the widespread distinction between two forms or types of knowledge, a broad approach was outlined. It should be noted that the two forms emphasised in this paper, labelled know-how and know-that, do not correspond simply to tacit and explicit knowledge since the former includes knowledge of which the knowers can and do tell and are consciously aware of. The utility of this distinction lies in that, building on ideas from Dewey and Schutz, we can propose that corresponding to these two apparent forms of knowledge are two modes of behaviour.

On the one hand we have the everyday life-world (Schutz and Luckmann, 1973), the world of non-reflectional experience (Dewey, [1916]) wherein we act in a non- 
reflectional manner; we simply get on with living, acting both consciously and unconsciously with respect to the objects of our conscious (and unconscious) attention. We typically do not think about how we are acting. On the other hand we have the world of reflective experience (Dewey, [1916]), phases of activity characterized by the conscious intent and attempt to analyse and describe some other experience or observed events with a view to communicating something to others, and perhaps for controlling those events. The work of scientists, loosely put, is a prime example of the latter type of behaviour.

The proposition then is that it seems useful to regard the two forms of knowledge as consequences (and also, to a degree, components) of two general modes of behaviour. Knowledge, on this account, is, and can perhaps only be, managed indirectly, through managing behaviour. In so far as know-how is a consequence/component of everyday behaving, any steps to influence the latter will affect know-how. Such techniques already exist and are used in, for example, sports coaching (Williams et al., 1999) and perhaps underpins some language teaching methods. Whether or not it is possible, let alone desirable, that we should consciously be able to structure someone's organizational everyday life-world such that they 'acquire' certain know-how is a matter for further debate and research. On the other hand we appear to know far more about how to guide and manage more explicitly reflectional processes. The whole field of research methodologies, for example, is concerned with how to conduct our behaviour vis-a-vis certain kinds of research objects, usually, but not always, with a view to obtaining inter-subjective agreement amongst researchers about those objects. Studies of scientific and other reflectional work are also to hand.

The broad implications for practice, both managerial and academic, of this hypothesis are clear. They are that know-how is influenced by all the actions we undertake. Whether it can be managed, in the sense that we ourselves, or someone else, can overtly influence know-how, is more difficult to determine. Good managers will be well aware that changing one aspect or condition of work often has adverse consequences for other aspects of behaviour. In so far as these are well-known and documented, they should perhaps be taken more seriously into account as having potentially adverse consequences for otherwise valuable know-how. Academics might take up the synthesis of what we already know about unplanned consequences of managerial actions, and formulate a research programme to develop this area. While non-reflectional behaviour goes on in every organization, of necessity, reflectional activities may not. Scientific 
work is often divorced from areas of its application, and is thus managed independently. But in so far as employees in any organization may, and may need, to reflect on what they are actually doing, they may derive assistance from formal research methodologies instead of relying on intuition. Academic research could also perhaps fruitfully consider to what extent and how reflective activity can become part and parcel of typical managerial work.

\section{REFERENCES}

Adler, P.S. (1995). 'Comment on I. Nonaka. Managing innovation as an organizational knowledge creation process'. In Allouche, J. and Pogorel, G. (Eds), Technology management and corporate strategies: a tricontinental perspective. Amsterdam: Elsevier, 110-124.

Ahituv, N. (1987). 'A metamodel of information flow: a tool to support information systems theory'. Communications of the ACM, 30, 9, 781-791.

Alexander, P.A., Schallert, D.L. and Hare, V.C. (1991). 'Coming to terms: how researchers in learning and literacy talk about knowledge'. Review of Educational Research, 61, 3, 315-343.

Alvesson, M. and Kärreman, D. (2001). 'Odd couple: making sense of the curious concept of knowledge management'. Journal of Management Studies, 38, 7, 995-1018. Ambrosini, V. and Bowman, C. (2001). 'Tacit knowledge: Some suggestions for operationalization'. Journal of Management Studies, 38, 6, 811-829.

Argote, L. and Darr, E. (2000). 'Repositories of knowledge in franchise organizations'. In Dosi, G., Nelson, R.R. and Winter, S.G. (Eds), The nature and dynamics of organizational capabilities. Oxford: Oxford University Press, 51-68.

Argote, L. and Ingram, P. (2000). 'Knowledge transfer: a basis for competitive advantage in firms'. Organizational Behavior and Human Decision Processes, 82 , 1, 150-169.

Argyris, C. and Schön, D.A. (1974). Theory in practice. Increasing professional effectiveness, San Francisco: Jossey-Bass.

Barfield, W.T. (n.d. [Preface dated 1947]). "Manna”. A comprehensive treatise on bread manufacture, 2nd edn. London: Maclaren \& Sons Ltd.

Barley, S.R. and Orr, J.E. (Eds) (1997). Between craft and science, Ithaca and London: 
Cornell University Press.

Bazerman, M. (1998). Judgement in managerial decision making, 4th edn. New York, Chichester: John Wiley \& Sons.

Becerra-Fernandez, I. and Sabherwal, R. (2001). 'Organizational knowledge management: a contingency perspective'. Journal of Management Information Systems, 18, 1, 23-55.

Bechtel, W. (1998). 'Representations and cognitive explanations: assessing the dynamicist's challenge in cognitive science'. Cognitive Science, 22, 3, 295-317.

Bechtel, W. and Richardson, R.C. (1993). Discovering complexity. Decomposition and localization as strategies in scientific research, Princeton, NJ: Princeton University Press.

Bereiter, C. (2002). Education and mind in the knowledge age, Mahwah, NJ; London: Lawrence Erlbaum Associates.

Berry, D.C. and Dienes, Z. (1993). Implicit learning. Theoretical and empirical issues, Hove: Lawrence Erlbaum Associates.

Blackler, F. (2002). 'Knowledge, knowledge work, and organizations. An overview and interpretation'. In Choo, C.W. and Bontis, N. (Eds), The strategic management of intellectual capital and organizational knowledge. Oxford: Oxford University Press, 4764.

Boiral, O. (2002). 'Tacit knowledge and environmental management'. Long Range Planning, 35, 291-317.

Bouthillier, F. and Shearer, K. (2002). 'Understanding knowledge management and information management: the need for an empirical perspective'. Information Research, 8, 1, (http://informationr.net/ir/8-1/paper141.html, accessed 5 March 2005).

Cherry, C. (1966). On human communication. A review, a survey and a criticism, 2nd edn. Cambridge MA, and London: MIT Press.

Choo, C.W. and Bontis, N. (Eds) (2002). The strategic management of intellectual capital and organizational knowledge, Oxford, New York: Oxford University Press.

Clancey, W.J. (1997a). Situated Cognition: on human knowledge and computer representations, Cambridge: Cambridge University Press. 
Clancey, W.J. (1997b). 'The conceptual nature of knowledge, situations and activity'. In Feltovich, P., Hoffman, R. and Ford, K. (Eds), Human and Machine Expertise in Context. Menlo Park: CA: The AAAI Press , 247-291.

Collins, H.M. (1974). 'The TEA set: tacit knowledge and scientific networks'. Science Studies, 4, 165-186.

Collins, H.M. (1993). 'The structure of knowledge'. Social Research, 60, 1, 95-116.

Collins, H.M. (2001a). 'Tacit knowledge, trust, and the Q of sapphire'. Social studies of science, 31, 1, 71-85.

Collins, H.M. (2001b). 'What is tacit knowledge?’. In Schatzki, T.R., Knorr Cetina, K. and von Savigny, E. (Eds), The practice turn in contemporary theory. London and New York: Routledge, 107-119.

Collins, H.M. and Kusch, M. (1998). The shape of actions. What humans and machines can do, Cambridge, MA.; London: MIT Press.

Cook, S.D.N. and Brown, J.S. (1999). 'Bridging epistemologies and the generative dance between organizational knowledge and organizational knowing'. Organization Science, 10, 4, 381-400.

Davenport, T. and Prusak, L. (1998). Working knowledge, Boston, MA: Harvard Business School Press.

Davenport, T.H., De Long, D.W. and Beers, M.C. (1998). 'Successful knowledge management projects'. Sloan Management Review, Winter, 43-57.

Davids, K. and Myers, C. (1990). 'The role of tacit knowledge in human skill performance'. Journal of Human Movement Studies, 19, 273-288.

Day, R.E. (2000). 'The "conduit metaphor" and the nature and politics of information studies'. Journal of the American Society for Information Science, 51, 9, 805-811.

Dewey, J. ([1916]). Essays in experimental logic, New York: Dover Publications.

Dewey, J. (1930). Human Nature and Conduct, New York: Random House.

Dewey, J. (1938). Logic: the theory of inquiry. Reprinted in Boydston, J. A. (ed). John Dewey. The Later Works, 1925-1953. Vol. 12: 1938. (1986). Carbondale \& Edwardsville: Southern Illinois University Press.

Dewey, J. and Bentley, A.F. (1949). Knowing and the Known, Boston: The Beacon 
Press.

Easterby-Smith, M. and Lyles, M.A. (2003). 'Introduction: watersheds of organizational learning and knowledge management'. In Easterby-Smith, M. and Lyles, M.A. (Eds), The Blackwell Handbook of Organizational Learning and Knowledge Management. Malden, MA; Oxford: Blackwell Publishing Ltd, 1-15.

Engeström, Y. (1999). 'Innovative learning in work teams: analyzing cycles of knowledge creation in practice'. In Engeström, Y. Miettinen, R. and Punamäki, R-L. (Eds), Perspectives on activity theory. Cambridge: Cambridge University Press, 377406.

Essers, J. and Schreinemakers, J. (1997). 'Nonaka's subjectivist conception of knowledge in corporate knowledge management'. Knowledge Organization, 24, 1, 2432.

Fletcher, K.E. and Huff, A.S. (1990). 'Argument mapping'. In Huff, A.S. (Ed.), Mapping Strategic Thought. Chichester, New York: John Wiley \& Sons, 355-376.

Friedman, V.J., Lipshitz, R. and Overmeer, W. (2001). 'Creating conditions for organizational learning'. In Dierkes, M., Antal, A.B., Child, J. and Nonaka, I. (Eds), Handbook of organizational learning and knowledge. Oxford: Oxford University Press, 757-774.

Frith, C. and Wolpert, D. (2004). The neuroscience of social interaction, Oxford: Oxford University Press.

Garavelli, A.C., Gorgoglione, M. and Scozzi, B. (2002). 'Managing knowledge transfer by knowledge technologies'. Technovation, 22, 269-279.

Garrick, J. (1998). Informal learning in the workplace, London \& New York: Routledge.

Gherardi, S. and Nicolini, D. (2000). 'To Transfer is to Transform: The Circulation of Safety Knowledge'. Organization, 7, 2, 329-348.

Gottlieb, G. (2001). 'A developmental psychobiological systems view: early formulation and current status'. In Oyama, S., Griffiths, P.E. and Gray, R.D. (Eds), Cycles of contingency. Developmental systems and evolutions. Cambridge, MA; London: MIT Press, 41-54.

Gourlay, S.N. (2004). 'Knowing as semiosis: steps towards a reconceptualization of 
'tacit knowledge'. In Tsoukas, H. and Mylonopoulos, N. (Eds), Organizations as Knowledge Systems. London: Palgrave Macmillan, 86-105.

Gray, B. (1996). 'Frame reflection'. Academy of Management Review, 21, 2, 576-579.

Griffin, D., Shaw, P. and Stacey, R. (1999). 'Knowing and acting in conditions of uncertainty: a complexity perspective'. Systematic practice and action research, 12, 3, 295-309.

Harris, C.C. (1980). Fundamental concepts and the sociological enterprise, London: Allen \& Unwin.

Herbig, B. and Büssing, A. (2003). 'Comparison of the role of explicit and implicit knowledge in working'. Psychology Science, 45, 3, 165-188.

Hildreth, P.M. and Kimble, C. (2002). 'The duality of knowledge'. Information Research, 8, 1, (http://informationr.net/ir/8-1/paper142.html, accessed 26 February 2005).

Holzner, B. (1972). Reality construction in society. (revised edition), Cambridge, MA: Schenkman Publishing Company.

Ichijo, K., von Krogh, G. and Nonaka, I. (1998). 'Knowledge enablers'. In von Krogh, G., Roos, J. and Kleine, D. (Eds), Knowing in firms. Understanding, managing and measuring knowledge. London: Sage, 173-203.

Imai, K., Nonaka, I. and Takeuchi, H. (1985). 'Managing the new product development process: how Japanese companies learn and unlearn'. In Clark, K.B., Hayes, R.H. and Lorenz, C. (Eds), The uneasy alliance. Managing the productivity-technology dilemma. Boston: Harvard Business School Press, 337-375.

Janik, A. (1988). 'Tacit knowledge, working life and scientific method'. In Göranzon, B. and Josefson, I. (Eds), Knowledge, skill and artificial intelligence. London \& Berlin: Springer-Verlag, 53-63.

Jorna, R. (1998). 'Managing knowledge'. Semiotic Review of Books, 9, 2, (http://www.chass.utoronto.ca/epc/srb/srb/managingknow.html, accessed 17 September 2000).

Kakihara, M. and Sørensen, C. (2002). 'Exploring knowledge emergence: from chaos to organizational knowledge'. Journal of Global Information Technology Management, 5, 3, 48-66. 
Klein, P.D. (1998). 'Knowledge, concept of'. In Craig, E. (Ed.), Routledge

Encyclopaedia of Philosophy. London \& New York: Routledge, 266-276.

Lado, A.A. and Wilson, M.C. (1994). 'Human resource systems and sustained competitive advantage: a competency-based perspective'. Academy of Management Review, 19, 4, 699-727.

Lakoff, G. and Johnson, M. (1980). Metaphors we live by, Chicago and London: Chicago University Press.

Liang, T.-Y. (1994). 'The basic entity model: a fundamental theoretical model of information and information processing'. Information Processing \& Management, 30, $5,647-661$.

Luper, S. (1998). 'Belief and knowledge'. In Craig, E. (Ed.), Routledge Encyclopaedia of Philosophy. London \& New York: Routledge, 706-709.

McAdam, R. and McCreedy, S. (1999). 'A critical review of knowledge management models'. The Learning Organization, 6, 3, 91-100.

Myers, P.S. (1996). Knowledge management and organizational design, Boston, Oxford: Butterworth-Heinemann.

Nisbett, R.E. and Wilson, T.D. (1977). 'Telling more than we can know: verbal reports on mental processes'. Psychological Review, 84, 3, 231-259.

Nonaka, I. (1988a). 'Toward middle-up-down management: accelerating information creation'. Sloan Management Review, 29, 3, 9-18.

Nonaka, I. (1988b). 'Creating order out of chaos: self-renewal in Japanese firms'. California Management Review, 15, 3, 57-73.

Nonaka, I. (1990). 'Redundant, overlapping organization: a Japanese approach to managing the innovation process'. California Management Review, 32, 3, 27-38. Nonaka, I. (1991a). 'The knowledge-creating company'. Harvard Business Review, November-December, 96-104.

Nonaka, I. (1991b). 'Managing the firm as an information creation process'. In Meindl, J.R., Cardy, R.L. and Puffer, S.M. (Eds), Advances in information processing in organizations. Greenwich, Conn., London: JAI Press Inc, 239-275.

Nonaka, I. (1994). 'A dynamic theory of organizational knowledge creation'. 
Organization Science, 5, 1, 14-37.

Nonaka, I. (1995). 'Managing innovation as an organizational knowledge creation process'. In Allouche, J. and Pogorel, G. (Eds), Technology management and corporate strategies: a tricontinental perspective. Amsterdam: Elsevier, 73-109.

Nonaka, I. and Kenney, M. (1991). 'Towards a new theory of innovation management: a case study comparing Canon, Inc. and Apple Computer, Inc.'. Journal of Engineering and Technology Management, 8, 1, 67-83.

Nonaka, I. and Takeuchi, H. (1995). The knowledge-creating company, New York, Oxford: Oxford University Press.

Nonaka, I. and Toyama, R. (2003). 'The knowledge-creating theory revisited: knowledge creation as a synthesizing process'. Knowledge Management Research \& Practice, 1, 1, 2-10.

Nonaka, I. and Yamanouchi, T. (1989). 'Managing innovation as a self-renewing process'. Journal of Business Venturing, 4, 299-315.

Nonaka, I., Byosière, P., Borucki, C.C. and Konno, N. (1994). 'Organizational Knowledge Creation Theory: a first comprehensive test'. International Business Review, 3, 4, 337-351.

Nonaka, I., Konno, N. and Toyama, R. (2001a). 'Emergence of "Ba". A conceptual framework for the continuous and self-transcending process of knowledge creation'. In Nonaka, I. and Nishigushi, T. (Eds), Knowledge Emergence. Social, technical and evolutionary dimensions of knowledge creation. Oxford, New York: Oxford University Press, 3-29.

Nonaka, I., Toyama, R. and Konno, N. (2001b). 'SECI, Ba, and leadership: a unified model of dynamic knowledge creation'. In Nonaka, I. and Teece, D. (Eds), Managing industrial knowledge. London, Thousand Oaks: Sage, 13-43.

Nonaka, I., Umemoto, K. and Senoo, D. (1996). 'From information processing to knowledge creation: a paradigm shift in business management'. Technology in Society, 18, 2, 203-218.

Patel, V.L., Arocha, J.F. and Kaufman, D.R. (1999). 'Expertise and tacit knowledge in medicine'. In Sternberg, R.J. and Horvath, J.A. (Eds), Tacit knowledge in professional practice. Mahwah, NJ and London: Lawrence Erlbaum Associates, 75-100. 
Poell, R.F. and van der Krogt, F.J. (2003). 'Learning strategies of workers in the knowledge-creating company'. Human Resource Development International, 6, 3, 387 403.

Polanyi, M. (1969). 'Knowing and Being'. In Grene, M. (Ed.), Knowing and Being. Essays. London: Routledge and Kegan Paul, 123-207.

Popper, M. and Lipshitz, R. (1998). 'Organizational learning mechanisms: a structural and cultural approach to organizational learning'. Journal of Applied Behavioral Science, 34, 2, 161-179.

Ratner, S. and Altman, J. (1964). John Dewey and Arthur F. Bentley. A Philosophical Correspondence 1932-1951, New Brunswick, NJ: Rutgers University Press.

Reed, M. (1985). Redirections in organizational analysis, London and New York: Tavistock Publications.

Richardson, K. (1998). Models of cognitive development, Hove: Psychology Press. Ryle, G. (1963). The concept of mind, Harmondsworth: Peregrine Books.

Sahdra, B. and Thagard, P. (2003). 'Procedural knowledge in molecular biology'. Philosophical psychology, 16, 4, 477-498.

Schaal, S., Ijspeert, A. and Billard, A. (2003). 'Computational approaches to motor learning by imitation'. In Frith, C. and Wolpert, D. (Eds), The neuroscience of social interaction. Oxford: Oxford University Press, 199-218.

Schutz, A., and Luckmann, T. (1974). The structures of the life-world. Vol. 1. London: Heinemann.

Shin, M., Holden, T. and Schmidt, R.A. (2001). 'From knowledge theory to management practice: towards an integrated approach'. Information Processing and Management, 37, 335-355.

Smith, F. (1994). Understanding reading, 5th edn. Hillsdale, NJ: Lawrence Erlbaum Associates.

Smith, L.B. and Samuelson, L.K. (2003). 'Different is good: connectionism and dynamic systems theory are complementary emergentist approaches to development'. Developmental Science, 6, 4, 434-439.

Spender, J.-C. (1996). 'Competitive advantage from tacit knowledge? Unpacking the 
concept and its strategic implication'. In Moingeon, B. and Edmondson, A. (Eds), Organizational learning and competitive advantage. London \& Thousand Oaks: Sage, 56-73.

Stacey, R.D. (2001). Complex responsive processes in organizations, London \& New York: Routledge.

Stamper, R. (1996). 'Signs, information, norms and systems'. In Holmqvist, B., Andersen, P.B., Klein, H. and Posner, R. (Eds), Signs of work. Berlin: Walter de Gruyter, 349-397.

Strauss, C. and Quinn, N. (1997). A cognitive theory of cultural meaning, Cambridge : Cambridge University Press.

Thompson, P. (1983). The nature of work, Basingstoke: Macmillan.

Torff, B. (1999). 'Tacit knowledge in teaching:: folk pedagogy and teacher education'. In Sternberg, R.J. and Horvath, J.A. (Eds), Tacit knowledge in professional practice. Mahwah, NJ and London: Lawrence Erlbaum Associates, 195-214.

Tsoukas, H. (2003). 'Do we really understand tacit knowledge?'. In Easterby-Smith, M. and Lyles, M.A. (Eds), The Blackwell Handbook of Organizational Learning and Knowledge Management. Malden, MA; Oxford: Blackwell Publishing Ltd, 410-427. Tsoukas, H. and Vladimirou, E. (2001). 'What is organizational knowledge?'. Journal of Management Studies, 38, 7, 973-993.

Tuomi, I. (1999). 'Data is more than knowledge: implications of the reversed knowledge hierarchy for knowledge management and organizational memory'. Proceedings of the 32nd Hawaii International Conference on System Sciences, IEEE. (http://www.computer.org/proceedings/hicss/0001/00011/00011071.PDF, accessed 2 March 2004).

Venzin, M., von Krogh, G. and Roos, J. (1998). 'Future research into knowledge management'. In von Krogh, G., Roos, J. and Kleine, D. (Eds), Knowing in firms. Understanding, managing and measuring knowledge. London: Sage, 27-66.

von Krogh, G. (1998). 'Care in knowledge creation'. California Management Review, 40, 3, 133-153.

von Krogh, G., Roos, J. and Slocum, K. (1996). 'An essay on corporate epistemology'. In von Krogh, G. and Roos, J. (Eds), Managing knowledge. Perspectives on 
cooperation and competition. 157-183.

Wagner, R.K. and Sternberg, R.J. (1986). 'Tacit knowledge and intelligence in the everyday world'. In Sternberg, R. J. and Wagner, R. K. Practical intelligence. Nature and origins of competence in the everyday world. Cambridge: Cambridge University Press, 51-83.

Weiskrantz, L. (1997). Consciousness lost and found, Oxford: Oxford University Press. Whitehill, M. (1997). 'Knowledge-based strategy to deliver sustained competitive advantage'. Long Range Planning, 30 , 4, 621-27.

Williams, A.M., Davids, K. and Williams, J.G. (1999). Visual perception and action in sport, London and New York: E \& F Spon.

Wilson, T.D. (2002). 'The nonsense of 'knowledge management'". Information Research, 8, 1, (http://informationr.net/ir/8-1/paper144.html, accessed 2 January 2004 Wohlschläger, A., Gattis, M. and Bekkering, H. (2003). 'Action generation and action perception in imitation: an instance of the ideomotor principle'. In Frith, C. and Wolpert, D. (Eds), The neuroscience of social interaction. Oxford: Oxford University Press, 131-158.

Yolles, M. (2000). 'Organizations, complexity, and viable knowledge management'. Kybernetes, 29, 9-10, 1202-1222. 
Figure 1: The "engine" of knowledge creation

(adapted from Nonaka \& Takeuchi, 1995, pp. 62, 71)

\begin{tabular}{|c|c|c|}
\hline tacit & Socialization & Externalization \\
\hline from & & \\
\hline explicit & Internalization & Combination \\
\hline
\end{tabular}


Table I: Knowledge types and names

\begin{tabular}{|c|c|c|}
\hline Discipline & Knowledge-how & Knowledge-that \\
\hline philosophy & $\begin{array}{l}\text { Knowledge-how; procedural } \\
\text { knowledge; abilities }\end{array}$ & $\begin{array}{l}\text { Knowledge-that; propositional } \\
\text { knowledge }\end{array}$ \\
\hline philosophy (Polanyi) $^{2}$ & Tacit knowing & Explicit knowledge \\
\hline psychology $^{1}$ & $\begin{array}{l}\text { Implicit knowledge; tacit } \\
\text { abilities; skills }\end{array}$ & $\begin{array}{l}\text { Explicit knowledge; } \\
\text { declarative knowledge }\end{array}$ \\
\hline artificial intelligence $^{1}$ & Procedural knowledge & Declarative knowledge \\
\hline neuroscience $^{3}$ & Covert knowledge & Overt knowledge \\
\hline $\begin{array}{l}\text { management studies } \\
\text { education }^{5}\end{array}$ & Tacit knowledge & Explicit knowledge \\
\hline 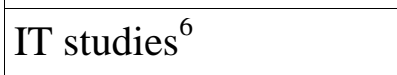 & Knowledge as process & Knowledge as object \\
\hline $\begin{array}{l}\text { knowledge } \\
\text { management }^{7}\end{array}$ & Know-how & Know-what \\
\hline sociology of science ${ }^{\gamma}$ & $\begin{array}{l}\text { Tacit; encultured (forms of } \\
\text { life) }\end{array}$ & Explicit/symbolic \\
\hline
\end{tabular}

Sources: (1) Sahdra and Thagard, 2003, p. 479; (2) Gourlay, 2004; (3) Weiskrantz, 1997, p. 256; (4) Nonaka and Takeuchi, 1995; (5) Alexander et al. 1991; (6) Kakihara and Sørensen, (2002); (7) Whitehill 1997; (8) Collins, 1993, 2001 b. 
NOTES

1 I would like to thank the editors, Professor Harry Collins, Andy Nurse, and three anonymous reviewers for their valuable comments on earlier drafts of this paper. Versions of it have been aired at Warwick University, Kingston University, and Copenhagen Business School - I am grateful to students and staff at those institutions for their comments. Errors of omission or commission remain my responsibility.

2 The theory appears originally to have been developed by Nonaka (e.g. Nonaka, 1991a, b; 1994) and subsequently presented in several collaborative publications (e.g. Nonaka et al., 1994; Nonaka and Takeuchi, 1995). Here 'Nonaka' and 'Nonaka and his colleagues' will be used interchangeably except where it is necessary to be more precise.

3 Nonaka (1994) was cited 543 times, and Nonaka and Takeuchi (1995) 1093 times between 1994, and June 2004. The number of citations has increased year on year, as has the range of categories of journals in which this publication has been cited (source: ISI Citation Indexes searched June 2004). Of course citations are made for many reasons, but this level of interest indicates these are considered very important works.

4 The volume of citations of their work (see Note 3 ) makes it difficult to be certain that all significant criticisms of their model have been identified. For this paper, abstracts of citations of Nonaka and Takeuchi (1995) were searched extensively for terms indicative of criticism or significant amendment: only six were found. Further criticism may have been published in edited volumes which are typically not indexed. However, had systematic criticism been published it would surely have been cited, and its absence, and the fact that no further suggestions were made during the refereeing process, suggests that none has yet appeared.

5 For additional criticism of details see in particular Becerra-Fernandez and Sabherwal (2001); Poell and van der Krogt (2003); Engeström (1999, pp. 380, 388-90); Griffin et al. (1999); Hildreth and Kimble, (2002); McAdam and McCreedy (1999, p. 96); Stacey, (2001, p. 35); and Yolles (2000).

6 Since justification can be based on false premises, epistemologists now prefer to define knowledge as “true, warranted, belief” rather than 'justified true belief' (Klein 
1998, p. 268).

7 They also proposed considering "knowledge as a dynamic human process of justifying personal belief toward the "truth."..." (Nonaka and Takeuchi, 1995, p. 58, their italics) but this processual notion did not inform further development of their theory.

8 Nonaka and his colleagues do not discuss 'belief' implicitly taking its meaning for granted, an unsound position since 'belief' is an ambiguous word (Dewey, 1938, p. 15). Luper (1998) indicates that the relationship between knowledge and belief is unclear.

9 Shin et al. (2001, pp. 337-339) distinguish a third category of knowledge perspectives, "belief in mind". Since 'beliefs in mind' are typically held to take the form of representations (Bechtel, 1998) this could be included in the decontextualized group, although were it to be argued that such beliefs only generate meaning in contexts, then it would belong to the context dependent group. Either way makes no difference in the present context. 